\title{
EFFICACY OF CURCUMIN AND MONOCHROMATIC LIGHT IN IMPROVING LIVER FUNCTIONS OF SEXUALLY MATURE MAGELANG DUCKS
}

\author{
Kasiyati $^{1,3}$, W. Manalu ${ }^{1}$, Sumiati ${ }^{2}$ and D. R. Ekastuti ${ }^{1}$ \\ ${ }^{1}$ Faculty of Veterinary Medicine, Bogor Agricultural University, \\ Jl. Agatis, Darmaga Campus, Bogor 16680 - Indonesia \\ ${ }^{2}$ Faculty of Animal Science, Bogor Agricultural University, \\ Jl. Agatis, Darmaga Campus, Bogor 16680 - Indonesia \\ ${ }^{3}$ Permanent Address: Faculty of Science and Mathematics, \\ Diponegoro University, Tembalang Campus, Semarang 50275 - Indonesia \\ Corresponding E-mail: atie_bd@yahoo.co.id
}

Received June 01, 2016; Accepted July 22, 2016

\begin{abstract}
ABSTRAK
Hati unggas betina memiliki peran vital sebagai tempat biosintesis prekursor kuning telur, karena perannya ini hati mudah mengalami kerusakan seluler. Tujuan penelitian ini ialah mengkaji efikasi suplementasi kurkumin dan penggunaan cahaya monokromatik dalam menekan histopatologi hati pada biosintesis kuning telur itik lokal. Pada penelitian ini digunakan seratus sembilan puluh dua ekor itik magelang betina. Rancangan penelitian yang digunakan ialah rancangan acak lengkap dengan susunan faktorial 4x4. Faktor pertama berupa dosis kurkumin, yaitu 0, 9, 18, dan $36 \mathrm{mg} / \mathrm{ekor} / \mathrm{hari}$. Faktor kedua adalah warna cahaya yang terdiri atas putih, merah, hijau, dan biru. Hasil penelitian menunjukkan bahwa degenerasi hidropik dan perlemakan pada hepatosit masih dalam kategori normal. Terdapat interaksi antara dosis kurkumin dan warna cahaya monokromatik yang menyebabkan penurunan konsentrasi serum glutamic-piruvic transaminase/glutamic-oxaloacetic transaminase (SGPT/GOT) dan malondyaldehid (MDA) hati $(\mathrm{P}<0,05)$, secara berurutan menurun hingga 24,63\%, 24,75\% dan 22,5\%. Peningkatan kadar trigliserida dan kolesterol berkorelasi positif dengan peningkatan SGPT/GOT serum dan MDA hati. Suplementasi kurkumin dan penambahan cahaya monokromatik dapat menghambat kerusakan oksidatif hati itik yang sedang mensintesis kuning telur sehingga kondisi patologis dapat ditekan.
\end{abstract}

Kata kunci: kurkumin, cahaya monokromatik, itik lokal, histopatologi hati

\begin{abstract}
The liver of female poultry has a vital role as an organ for biosynthesis of the yolk precursor and has a great chance of experiencing cellular damages. This experiment was designed to study the uses of curcumin and monochromatic light in suppressing liver destruction during the period of yolk biosynthesis in Magelang ducks. One hundred and ninety two female Magelang ducks were assigned into a completely randomized design with a $4 \times 4$ factorial arrangement. The first factor was dose of curcumin supplementation consisted of 4 levels i.e., $0,9,18$, and $36 \mathrm{mg} /$ duck/day. The second factor was the color of monochromatic light consisted of 4 levels i.e., white, red, green, and blue. The results showed that hydropic and fat degenerations in the livers of Magelang ducks entering laying phase were still in a normal range. There was an interaction effect between curcumin and monochromatic light on the serum SGPT/GOT and liver MDA concentrations $(\mathrm{P}<0.05)$. Serum lipid concentrations positively correlated with the increased serum SGPT/GOT and liver MDA concentrations as indicators of liver
\end{abstract}


damages. Supplementation of curcumin and the use of monochromatic light could reduce and suppress liver destruction and damage during laying period in female Magelang ducks.

Keywords: curcumin, monochromatic light, local ducks, liver histopathology

\section{INTRODUCTION}

Egg production in poultry is always linked to various metabolic stresses that can decrease the production and reproduction performances. Most of metabolic stresses experienced by the poultry during laying period are oxidative stresses that occurred at the cellular levels (Surai, 2016). The liver of laying poultry has a vital role as a main organ synthesizing the precursors of yolk materials during laying period to be deposited in the form of lipoprotein complex into the ovary. The increased metabolic activities in the liver cells in supporting egg production during laying period is associated with the increased production of peroxidation and free radicals that have hepatotoxic effects which lead to the decreased liver function and even cellular damage that causes pathological condition (Lien et al., 1999). The increased lipid peroxidation and free radical production can be triggered by the oxidative stress. Free radical is an unstable molecule that can damage the cell structure through the reaction of lipid oxidation. The increased liver malondyaldehid (MDA) level is an indicator of lipid peroxidation that causes pathological condition. The concentrations of serum glutamicpyruvic transaminase (SGPT) and serum glutamic-oxaloacetic transaminase (SGOT) enzymes in the plasma will also increase with the decreased level of antioxidants. Both enzymes are the biomarkers of the oxidative damage in the liver tissues and the indicators of liver toxicity (Rajput et al., 2013; Li et al., 2014).

Curcumin, an active compound of turmeric, serves as an antioxidant and anti-inflammation with its efficacy as a hepatoprotector, antimicrobe, and anti-carcinogen. From various researches so far, there was no report about the toxicity of curcumin or turmeric powder as a food supplement for rats, guinea pigs, monkeys, and pigs (Al-Sultan and Gameel, 2004).

Sexual maturity and reproduction performance of the poultry can be modulated by lighting management. Light can be detected by the eye photoreceptor, pineal glands, and hypothalamus so that it causes ovarian activity, sexual maturity, and egg production. Photoperiod is very essential in controlling the poultry's growth, sexual maturity, and reproductive performance, health, and behavior (Baxter et al., 2014; Borille et al., 2015). This research was designed to study the efficacy of curcumin supplementation and the role of monochromatic light in reducing the liver damages during laying period in Magelang ducks.

\section{MATERIALS AND METHODS}

\section{Local Ducks, Breeding Management, and Research Design}

One hundred and ninety two female Magelang ducks at the age of 16 weeks with live weight of $1500 \pm 0.09 \mathrm{~g}$ obtained from Breeding Center for Non-Ruminant Livestock Farming in Banyubiru, Ambarawa, Central Java, were chosen randomly and placed into 48 cages plots to be acclimated for one week. Each cage plot consisted of four ducks. The research cages were in the form of litter system with a base made of rice husk mixed with calcite. Every cage plot had a size of $100 \times 170 \times 75 \mathrm{~cm}^{3}$, equipped with the feeding container and two nipple drinkers, and cages were partitioned by wooden slats coated with calcirata (GRC board).

The source of monochromatic light was light emitting diode (LED) with the color of white, red, green, and blue, G45 type Koss, $220 \mathrm{~V}$. The lights were arranged in series, placed on the top center in each cage plot. The light source was $70 \mathrm{~cm}$ away from the floor of the cage in order to obtain intensity of $10 \mathrm{~lx}$ for each cage. The light intensity was measured by using luxmeter (Lutron Taiwan, LX-100) every week at five points for every cage plot. The lamp circuit was equipped with an adaptor, stabilizer, and timer. Monochromatic light was given for five hours every day, from 6 p.m. to 11 p.m. so that the photoperiod used was 17 hours light period and 7 hours dark period every day (17 L:7 D).

The ducks were raised at the environmental temperature of $28-32{ }^{\circ} \mathrm{C}$, the feed and drinking water were provided ad libitum. The feed used during the experiment was in the form of semiwet mash formulated with curcumin, adjusted with the nutrient need of the breeder ducks at the growth period of 16-20 weeks (grower) and production period of 21-25 weeks (breeder) with 
the different protein contents and metabolizable energy. The composition and nutrient contents of the ration used was calculated by using Excel program (Table 1). The feed formulation for every stage of duck breeding was arranged according to the recommendation of Leeson and Summers (2005). Curcumin extract powder $(78.94 \%)$ was obtained from 95\% curcuminoid (Plamed Green
Science Ltd, China). The protocol of the experiment was approved by Animal Ethics Committee, Faculty of Veterinary Medicine, Bogor Agricultural University.

The experiment used Completely Randomized Design with a 4x4 factorial arrangement. The first factor was dose of curcumin supplementation with 4 levels i.e., 0,9 ,

Table 1. Feed Composition and Nutrient Content for Each Phase of Local Duck Breeding

\begin{tabular}{lcc}
\hline \multicolumn{1}{c}{ Feed composition (\%) } & Grower (16-20 weeks) & Production $(21-25$ weeks $)$ \\
\hline Yellow corn & 57.00 & 58.00 \\
Rice barn & 15.00 & 11.05 \\
Corn gluten meal & 6.00 & 3.50 \\
Soybean meal & 11.00 & 13.00 \\
Fishmeal & 5.15 & 3.50 \\
Palm oil & 4.00 & 2.70 \\
Dicalcium phosphate & 0.10 & 0.10 \\
CaCO3 & 1.25 & 7.50 \\
Salt & 0.20 & 0.10 \\
Premix* & 0.30 & 0.30 \\
L-lysine & 0 & 0.10 \\
DL-methionine & 0 & 0.15 \\
Total & 100.00 & 100.00
\end{tabular}

Nutrient content from calculation result

\begin{tabular}{lrr} 
Metabolizable energy (kcal/kg) & 3133.13 & 2898.95 \\
Protein (\%) & 18.01 & 16.02 \\
Fat (\%) & 7.22 & 5.08 \\
Crude fibers (\%) & 3.76 & 3.29 \\
Lysine (\%) & 0.87 & 0.91 \\
Methionine (\%) & 0.43 & 0.51 \\
Methionine+Cysteine (\%) & 0.70 & 0.76 \\
Linoleic acid (\%) & 2.02 & 1.72 \\
$\mathrm{Ca}(\%)$ & 0.88 & 3.14 \\
$\mathrm{P}(\%)$ & 0.47 & 0.38 \\
$\mathrm{Na}(\%)$ & 0.16 & 0.11 \\
$\mathrm{Cl}(\%)$ & 0.21 & 0.14 \\
\hline
\end{tabular}

*) Each kg of premix contains: Vit A, 1.200.000 IU; Vit D3, 200.000 IU; Vit E, 800 mg; Vit K, 200 mg; Vit B1, $200 \mathrm{mg}$; Vit B2, $500 \mathrm{mg}$; Vit B6, $50 \mathrm{mg}$; Vit C, $2500 \mathrm{mg}$; DL-methionine, $8000 \mathrm{mg}$; L-lysine, $3000 \mathrm{mg}$; Ca, 280.000 mg; P, 150.000 mg; Mn, 12.000 mg; Fe, 2000 mg; I, 20 mg; Co, 20 mg; Zn, 10.000 mg; dan Cu, $400 \mathrm{mg}$ 
18 , and $36 \mathrm{mg} /$ duck/day. The second factor was the color of monochromatic light consisted of 4 levels i.e., white, red, green, and blue. Each treatment was replicated three times and each replication was used 4 Magelang ducks. The experimental rations were given twice a day at 7 a.m. and 3 p.m. The treatments were given for eight weeks, starting at the age of 17 weeks until 25 weeks.

\section{Sample Collection and Parameter Measurement}

The blood collection and liver isolation were conducted after 8 weeks of treatment when the ducks reached 25 weeks of age or undergone sexual maturity. Each treatment was represented by three ducks to be slaughtered by cutting the vein and jugular artery, esophagus, and trachea. The blood was then collected in a $10 \mathrm{ml}$ of test tube for each duck. The test tubes containing blood were allowed to stand for 24 hours at a temperature of $4{ }^{\circ} \mathrm{C}$, and were later centrifuged at $3000 \mathrm{rpm}$ for 10 minutes. The serum was removed and transferred into an eppendorf tube, stored at $-20^{\circ} \mathrm{C}$ for further analysis of serum glutamicpyruvic transaminase (SGPT) and serum glutamic-oxaloacetic transaminase (SGOT) concentrations by using Reitman and Frankel method (Bigoniya et al., 2009). The liver was isolated and subsequently cut into a $1 \times 1 \mathrm{~cm}^{2}$ and stored in $10 \%$ buffered neutral formalin solution for histological preparation. The qualitative observation of the liver histopathology was determined by the description of the liver histology by using paraffin method and Haematoxcillin-Eosin staining (Bancroft and Gamble, 2008). Histomorphology of the liver was observed by using Olympus CX-52 microscope with Olympus DP2-BSW software. To analyze the liver MDA, $3 \mathrm{~g}$ of the liver was chopped in cold condition. The MDA concentrations of the liver to determine the peroxidation activity of liver cell membranes was measured by using the TBA method (Ohkawa et al., 1979).

\section{Statistical Analysis}

The data were analyzed using Analysis of Variance (ANOVA). The whole data analysis were conducted by general linear model procedure on SAS v9.0 program (SAS Institute, 2002). In order to determine the relationship of each parameter, the correlation coefficient $(r)$ and the coefficient of determination $\left(\mathrm{R}^{2}\right)$ were calculated.

\section{RESULTS AND DISCUSSION}

Curcumin supplementation and the use of monochromatic light caused the morphological changes in the hepatocytes. Generally, the changes that occurred were hydropic and fat degenerations with various degrees of severity of fatty liver (Table 2). Hydropic degeneration (vacuolation) was observed in the livers of the experimental ducks without supplemented curcumin (control) and using white, red, and blue lights. The nucleus of the liver cells that underwent hydropic degeneration was still in the center. The liver cells of the ducks that showed hydropic degeneration contained more fluid. This condition was more prevalence when the ducks reached sexual maturity and were under energy deficiency so that the regulation of osmolarity of cellular fluid was disturbed. In contrast, fatty degeneration was observed in most ducks supplemented with curcumin. The hepatocytes of these experimental ducks showed vacuoles containing fat droplets and the increased fat concentration in the vacuole could push the nucleus into the peripheral site. Hydropic and fat degenerations that were observed in the liver of sexually mature ducks were still in normal category, so that it could be used as an indicator of synthesis of yolk precursors in the hepatocytes when the ducks were entering sexual maturity and during the laying period. The fat component of the yolk is synthesized by hepatocytes and is secreted into the circulation for further deposition in the developing oocytes in the ovary. In this research even though the vacuoles of the liver cells contained more fat it did not indicate the pathological condition.

Hydropic degeneration is reversible and it can be irreversible if the plasma membrane is broken and leads to the death of the cells (necrosis). Fatty degeneration starts with the formation of small vacuole (micro vesicle) containing a little fat around the endoplasmic reticulum (liposome) and at the final stage, the size of the vacuole is bigger (macro vesicle) so that it pushes the nucleus to the peripheral site of hepatocyte (Shini, 2014). Related to liver pathology, Hermier (1997) and Aydin et al. (2005) reported that the metabolic disruption in the form of fatty liver could occur in breeder poultry that were producing egg because of the failure of fat transport by lipoprotein so that the fat was accumulated extensively in the hepatocyte. The first emerging sign in this metabolic disruption is 
Table 2. Changes in Liver Histomorphology in Sexually Mature of Magelang Ducks

\begin{tabular}{|c|c|c|c|c|c|}
\hline \multirow[b]{2}{*}{ Treatment } & \multicolumn{2}{|c|}{ Histomorphology changes } & \multirow[b]{2}{*}{ Treatment } & \multicolumn{2}{|c|}{ Histomorphology changes } \\
\hline & $\begin{array}{c}\text { Hydropic } \\
\text { degeneration }\end{array}$ & $\begin{array}{c}\text { Fatty } \\
\text { degeneration }\end{array}$ & & $\begin{array}{c}\text { Hydropic } \\
\text { degeneration }\end{array}$ & $\begin{array}{c}\text { Fatty } \\
\text { degeneration }\end{array}$ \\
\hline A & +++ & + & I & + & ++ \\
\hline B & + & + & $\mathrm{J}$ & _ & ++++ \\
\hline $\mathrm{C}$ & _ & +++ & $\mathrm{K}$ & _- & +++ \\
\hline $\mathrm{D}$ & + & + & $\mathrm{L}$ & _ & ++ \\
\hline $\mathrm{E}$ & - & +++ & M & _- & ++ \\
\hline $\mathrm{F}$ & _- & +++ & $\mathrm{N}$ & _ & ++ \\
\hline G & _ & ++ & $\mathrm{O}$ & _ & ++ \\
\hline $\mathrm{H}$ & _- & ++++ & $\mathrm{P}$ & _ & ++++ \\
\hline
\end{tabular}

A-D: curcumin supplementation at a dose $0 \mathrm{mg}$ with white, red, green, and blue lights, respectively; E-H: curcumin supplementation at a dose of $9 \mathrm{mg}$ with white, red, green, and blue lights, respectively; I-L: curcumin supplementation at a dose of $18 \mathrm{mg}$ with white, red, green, and blue lights, respectively; M-P: curcumin supplementation at a dose of $36 \mathrm{mg}$ with white, red, green, and blue lights.

the increase in mortality rate, the larger size of liver organ with pale colors, swollen liver cells because of the fat in the vacuole, and the different sizes of hepatocytes due to hemorrhage.

The degree of liver damage can be measured by measuring the enzymes activity in the microsome and liver cytosol, such as SGPT and SGOT. The interaction between curcumin doses with monochromatic light decreased the activity of SGPT/GOT $(\mathrm{P}<0.05)$ of the experimental ducks entering sexual maturity (Table 3 ). The experimental ducks supplemented with curcumin with a dose of $36 \mathrm{mg}$ and exposed to blue light had lower activity of SGPT by $24.63 \%$ and SGOT activity by $24.75 \%$. There was an indication that the increased dose of curcumin supplementation and exposure to the red, green, and blue lights could decrease SGPT/GOT production. It means that the damage of liver cells can be reduced and suppressed during the biosynthesis of yolk precursor in the laying ducks. In this experiment, the SGPT/GOT concentrations positively correlated with the serum triglyceride and cholesterol concentrations and liver MDA (Table 4).

The damage of liver cells was marked with the broken or the loss of cellular membrane integrity so that it triggered the flow of SGPT/GOT from the cells into the circulation. The concentrations of those enzymes increase with the increased degree of liver damage so that it can be used as indicator of liver pathology (Adriani et al., 2014). Curcumin had a positive effect on the liver functions as indicated by the decreased activities of serum SGPT/GOT and ALP (alkaline phosphatase) (Gandhi et al., 2011). Curcumin has a strong antioxidant activity due to its ability to trap or cleanse free radicals. This capacity is supported by the chemical structure of curcumin in the form of metoxilation phenol and enol with the form of $\beta$-diketone, that effectively cleanses free radicals by breaking oxidant chains (Radwan et al., 2008).

The increase in liver damage during the period of sexual maturity was also strengthened by the high level of MDA in the liver of control experimental ducks $(\mathrm{P}<0.05)$. The concentrations of MDA in the liver were influenced by the dose of curcumin supplementation, the color of monochromatic light used, and interaction between dose of curcumin supplementation and the color of monochromatic light used (Table 3 ). The result of this experiment indicated that the increased dose of curcumin supplementation decreased the MDA production in duck's liver tissue by $16.82 \%\left(0.07 \mathrm{mg} \mathrm{kg}^{-1}\right)$, while the blue light could decrease the liver MDA by $22.5 \%$ $\left(0.09 \mathrm{mg} \mathrm{kg}^{-1}\right)$. The level of MDA in the liver also had positive correlation with serum triglyceride 
Table 3. The Serum of SGPT and SGOT Level, and Liver MDA of Magelang Ducks

\begin{tabular}{|c|c|c|c|c|c|}
\hline \multirow{2}{*}{ Light colors } & \multicolumn{4}{|c|}{ Curcumin doses (mg/duck/day) } & \multirow{2}{*}{ Mean } \\
\hline & 0 & 9 & 18 & 36 & \\
\hline \multicolumn{6}{|l|}{ SGPT (U/L) } \\
\hline White & $36.74 \pm 0.18^{\mathrm{a}}$ & $34.52 \pm 0.28^{\mathrm{d}}$ & $31.93 \pm 0.09^{f}$ & $31.02 \pm 0.10^{\mathrm{g}}$ & $33.56^{\mathrm{a}}$ \\
\hline Red & $36.11 \pm 0.34^{\mathrm{b}}$ & $33.26 \pm 0.28^{\mathrm{e}}$ & $31.33 \pm 0.12^{\mathrm{g}}$ & $30.58 \pm 0.27^{\mathrm{h}}$ & $32.82^{\mathrm{b}}$ \\
\hline Green & $35.49 \pm 0.08^{\mathrm{c}}$ & $32.32 \pm 0.21^{\mathrm{f}}$ & $31.39 \pm 0.31^{\mathrm{g}}$ & $30.18 \pm 0.07^{\mathrm{h}}$ & $32.34^{\mathrm{c}}$ \\
\hline Blue & $35.28 \pm 0.05^{\mathrm{c}}$ & $32.31 \pm 0.16^{\mathrm{f}}$ & $31.92 \pm 0.56^{\mathrm{f}}$ & $29.51 \pm 0.25^{\mathrm{i}}$ & $32.26^{\mathrm{c}}$ \\
\hline Mean & $35.90^{\mathrm{a}}$ & $33.11^{\mathrm{b}}$ & $31.64^{\mathrm{c}}$ & $30.32^{\mathrm{d}}$ & \\
\hline \multicolumn{6}{|l|}{ SGOT (U/L) } \\
\hline White & $33.28 \pm 0.06^{\mathrm{a}}$ & $31.74 \pm 0.05^{\mathrm{d}}$ & $30.23 \pm 0.05^{\mathrm{f}}$ & $30.01 \pm 0.05^{\mathrm{f}}$ & $31.32^{\mathrm{a}}$ \\
\hline Red & $32.66 \pm 0.04^{\mathrm{b}}$ & $31.35 \pm 0.04^{\mathrm{d}}$ & $30.36 \pm 0.02^{\mathrm{f}}$ & $29.42 \pm 0.05^{\mathrm{gh}}$ & $30.95^{\mathrm{b}}$ \\
\hline Green & $31.19 \pm 0.12^{\mathrm{c}}$ & $31.36 \pm 0.07^{\mathrm{d}}$ & $29.61 \pm 0.06^{\mathrm{g}}$ & $29.15 \pm 0.02^{\mathrm{h}}$ & $30.58^{\mathrm{c}}$ \\
\hline Blue & $32.14 \pm 0.05^{\mathrm{c}}$ & $30.76 \pm 0.04^{\mathrm{e}}$ & $30.36 \pm 0.06^{\mathrm{f}}$ & $29.21 \pm 0.08^{\mathrm{gh}}$ & $30.654^{\mathrm{c}}$ \\
\hline Mean & $32.575^{\mathrm{a}}$ & $3.59^{\mathrm{b}}$ & $30.07^{\mathrm{b}}$ & $4.36^{\mathrm{d}}$ & \\
\hline \multicolumn{6}{|l|}{$\operatorname{MDA}\left(\mathrm{mg} \mathrm{kg}^{-1}\right)$} \\
\hline White & $0.13 \pm 0.03^{b c}$ & $0.12 \pm 0.02^{\mathrm{d}}$ & $0.09 \pm 0.03^{\mathrm{fg}}$ & $0.08 \pm 0.05^{\mathrm{hi}}$ & $0.10^{\mathrm{b}}$ \\
\hline Red & $0.18 \pm 0.01^{\mathrm{a}}$ & $0.11 \pm 0.04^{\mathrm{de}}$ & $0.08 \pm 0.03^{\mathrm{hi}}$ & $0.08 \pm 0.03^{\mathrm{hi}}$ & $0.11^{\mathrm{a}}$ \\
\hline Green & $0.14 \pm 0.03^{\mathrm{b}}$ & $0.12 \pm 0.03^{\mathrm{d}}$ & $0.10 \pm 0.04^{\mathrm{ef}}$ & $0.07 \pm 0.04^{\mathrm{i}}$ & $0.10^{\mathrm{b}}$ \\
\hline Blue & $0.13 \pm 0.04^{b c}$ & $0.10 \pm 0.05^{\mathrm{ef}}$ & $0.09 \pm 0.04^{\mathrm{fg}}$ & $0.08 \pm 0.04^{\mathrm{hi}}$ & $0.09^{\mathrm{c}}$ \\
\hline Mean & $0.15^{\mathrm{a}}$ & $0.11^{\mathrm{b}}$ & $0.09^{\mathrm{c}}$ & $0.078^{\mathrm{d}}$ & \\
\hline
\end{tabular}

${ }^{\mathrm{a}-\mathrm{d}}$ Mean values within row with different superscripts shows significantly different $(\mathrm{P}<0.05)$.

${ }^{\mathrm{a}-\mathrm{c}}$ Mean values within column with different superscripts shows significantly different $(\mathrm{P}<0.05)$.

${ }^{\mathrm{i}-1}$ Mean values within row and column with different superscripts shows significantly different $(\mathrm{P}<0.05)$. The data are shown as mean \pm SD.

and cholesterol concentrations (Table 4). It can be concluded that the increases of triglyceride and serum cholesterol levels (data not shown) increase the oxidation of lipid so that it seriously increases the degree of liver cells damage.

Curcumin has an activity to reduce the lipid peroxidation by increasing the antioxidant enzymes and protect mitochondria from oxidative damage due to the increase in the synthesis of ATP for the increased yolk biosynthesis. In this experiment, the combination between the curcumin and the color of monochromatic lights could suppress the lipid peroxidation in the liver cells of the ducks entering sexual maturity as was marked by the low level of liver MDA. There was an indication that the higher the dose of curcumin supplementation the higher the degree of suppression of production of liver MDA. In parallel with the results of Rajput et al. (2013), the curcumin supplementation significantly decreased or prevented the lipid peroxidation by free radical in the broiler as was indicated by the low level of liver MDA. Wang et al. (2011) also reporting that the increased MDA will decrease the energy on the antioxidant system, thus results in lipid peroxidation. This lipid peroxidation does not only transfers reactive oxygen but also generates new free radicals, and the amount of reactive oxygen is increasing. This condition can result in bio-membrane degeneration and the 
Table 4. Linear Regression Analysis on Lipid Profile with the Extent of Liver Damage

\begin{tabular}{lcclcc}
\hline \multicolumn{1}{c}{ Correlation } & $\mathrm{R}$ & $\mathrm{R}^{2}(\%)$ & \multicolumn{1}{c}{ Correlation } & $\mathrm{R}$ & $\mathrm{R}^{2}(\%)$ \\
\hline Triglycerides vs SGPT & 0.99 & 97 & Triglycerides vs liver MDA & 0.91 & 84 \\
Cholesterol vs SGPT & 0.85 & 72 & Cholesterol vs liver MDA & 0.77 & 59 \\
Triglycerides vs SGOT & 0.98 & 96 & SGPT vs liver MDA & 0.89 & 79 \\
Cholesterol vs SGOT & 0.87 & 74 & SGOT vs liver MDA & 0.88 & 77 \\
\hline
\end{tabular}

damage of cellular structures that leads to pathological condition.

\section{CONCLUSION}

Our study shows that curcumin supplementation at the doses of 9-36 mg/duck/day and the exposure of the experimental ducks to monochromatic light could inhibit the liver oxidative damage of local ducks that are synthesizing of yolk so that pathological condition can be suppressed.

\section{REFERENCES}

Adriani, L., A. Rochana, A. Yulianti, A. Mushawwir and N. Indrayani. 2014. Profil serum glutamate oxaloacetat transaminase (SGOT) and glutamate pyruvate transaminase (SGPT) level of broiler that was given noni juice (Morinda citrifolia) and palm sugar (Arenga piata). Luc. Stii. Ser. Zoo. 62:101-105.

Al-Sultan, S.I. and A.A. Gameel. 2004. Histopathological changes in the liver of broiler chicken supplemented with turmeric (Curcuma longa). Inter. J. Poult. Sci. 3(5): 333-336.

Aydin, R. 2005. Type of fatty acid, lipoprotein secretion from liver and fatty liver sindrome in laying hens. Inter. J. Poult. Sci. 4(11): 917-919.

Bancroft, J.D. and M. Gamble. 2008. Theory and Practice of Histological Techniques. 6th ed. Churchill Livingstone, Elsevier, China.

Baxter, M., N. Joseph, R. Osborne and G.Y. Bédécarrats. 2014. Red light is necessary to activate the reproduction axis in chickens independently of the retina of the eye. Poult Sci. 93: 1289-1297.

Bigoniya, P., C.S. Sing and A. Shukla. 2009. A comprehensive review of different liver toxicants used in experimental pharmacology. Inter. J. Pharm. Sci. Drug. Res. 1:124-135.

Borille, R., R.G. Garcia, I.A. Naas, F.R. Caldara and M.R. Santana. 2015. Monochromatic light emitting diode (LED) source in layers hens during the second production cycle. R. Bras. Eng. Agric. Ambiental. 19(9): 877881.

Gandhi, P., Z. Khan and N. Chakraverty. 2011. Soluble curcumin: a promising oral supplement for health management. J. App. Pharm. Sci. 01(02): 01-07.

Hermier, D. 1997. Lipoprotein Metabolism and fattening in poultry. J. Nutr. 127: 805-808.

Leeson, S. and J.D. Summers. 2005. Commercial Poultry Nutrition. 3rd ed. Nottingham Univ Press. England.

Li, Y., Q.G. Ma, L.H. Zhao, Y.Q. Guo, G.X. Duan, J.Y. Zhang and C. Ji. 2014. Protective efficacy of alpha-lipolic acid against aflatoxinB1-induced oxidative damage in the liver. Asian-Aus. J. Anim. Sci. 27(6): 907-915.

Lien, T.F. and D.F. Jan. The effect of the metabolism of tsiya ducks when high levels of choline or methionine are added to the duck's diet. Asian-Aus. J. Anim. Sci. 12(7): 1090-1095.

Ohkawa, H., N. Ohishi and K. Yagi, 1979. Assay for lipid peroxides in animal tissues by thiobarbituric acid reaction. Anal. Biochem. 95: 351-358.

Radwan, N.L., R.A. Hassan, E.M. Qota and H.M. Fayek. 2008. Effect of natural antioxidant on oxidative stability of eggs and productive and reproductive performance of laying hens. Intr. J. Poult. Sci. 7(2):134-150.

Rajput, N., N. Muhammad, S. Ali, J.F. Zhang, and L. Zhang. 2013. The effect of dietary 
supplementation with the natural carotenoids curcuma and lutein on broiler pigmentation and immunity. Poult. Sci. 92:1177-1185.

SAS Institute. 2002. The SAS System for Windows. V9.0. SAS Institute Inc. Cary, NC.

Shini, A. 2014. Fatty Liver Haemorrhagic Syndrome in Laying Hens: Field and Experimental Investigations. $\mathrm{PhD}$ Thesis. School of Agricultural and Food Sciences.
The University of Queensland.

Surai, P.F. 2016. Antioxidant system in the poultry biology: superoxide dismutase. Imedpub. J. 1(18):1-17.

Wang, H., X. Zhong, W. Shi and B. Guo. 2011. Study of malondialdehyde (MDA) content, superoxide dismutase (SOD) and glutathione peroxidase (GSH-Px) activities in chickens infected with avian infectious bronchitis virus. Afr. J. Biotech. 10(45):9213-9217. 